\title{
Effects of Cocaine on Dopamine Receptor Gene Expression: A Study in the Postmortem Human Brain
}

\author{
James H. Meador-Woodruff, Karley Y. Little, Scott P. Damask, \\ Alfred Mansour, and Stanley J. Watson
}

\begin{abstract}
The effects of chronic cocaine exposure on dopamine $D_{1}$ and $D_{2}$ receptor gene expression in the human brain were studied in postmontem samples from chronic cocaine abusing and matched control subjects. Using in situ hybridization and receptor autoradiography to examine messe. ger ribonucleic acid (RNA) and binding sites, respectively, neither $D_{1}$ nor $D_{2}$ receptor expression was found to be changed in the nucleus accumbens, caudate, putamen, or substantia nigra of the cocaine-exposed subjects. Although chronic cocaine exposure can produce alterations in dopaminergic neurotransmission, sustained compensatory changes in dopamine receptor expression do not appear to occur in the human.
\end{abstract}

Key Words: Receptors, dopamine, messenger RNA, in situ hybridization, cocaine, receptor binding, human brain

\section{Introduction}

Cocaine has myriad effects on a number of neurotransmitter systems in the brain. While influencing multiple systems, however, its effects on dopaminergic neurotransmission in the limbic system appear to be a critical mechanism underlying the reinforcing properties of this drug (Kuhar et al 1991). Cocaine is able to block the dopamine transporter, which acts as a presynaptic reuptake site, thus effectively increasing intrasynaptic dopamine concentration (Ritz et al 1987; Church et al 1987; Izenwasser et al 1990). There is some evidence that there may be com-

\footnotetext{
From the Mental Heaith Research Institute and Department of Psychiatry, University of Michigan Medical Center, Ann Arbor, Michigan (JHM-W, AM, SPD. SJW), and Department of Psychiatry, University of North Caroline, Chapel Hill, North Carolina (KYL)

Address reprint requests to Dr. James $H$. Meador-Woodruff, Mental Health Research Institute, Department of Psychiatry, University of Michigan, 205 Zina Pitcher Place, Ann Arbor, Michigan 48109-0720.

Received March 3. 1993; revised June 3, 1993.
}

pensatory changes in dopamine receptor expression as well, which could be a primary effect or a secondary result of this increased intrasynaptic dopamine (Trulson and Ulissey 1987; Goeders and Kuhar 1987; Kleven et al 1990; Volkow et al 1990; Peris et al 1990; Mayfield et al 1992; Farfel et al 1992).

The mesolimbic component of the dopamine system is one of the most likely sites of action of cocaine in the brain. This system originates in the dopamine-synthesizing cells of the ventral tegmental area, located in the medial mesencephalon, which send axons rostrally to terminate in limbic regions of the brain, including the nucleus accumbens. Parallel to this system, the nigrostriatal system arises more laterally in the midbrain, sending fibers to the caudate and putamen. The nucleus accumbens as well as the caudate and putamen send fibers back to the midbrain cell groups, thus completing discrete neuroanatomical circuits associated with reinforcement and motor functions.

The specific subtypes of dopamine receptors located in these circuits appear to be complex. Although both $D_{1}$ and 
$D_{2}$ receptors have been identified in all anatomical regions associated with these systems, the recent cloning of multiple dopamine receptor subtypes in the human has revealed an additional level of neurochemical organization. The dopamine receptors cluster into two larger families: the $D_{1}$-like family contains the $D_{1}$ (Dearry et al 1990; Zhou et al 1990; Sunahara et al 1990) and $D_{5}$ (Sunahara et al 1991; Weinshank et al 1991; Grandy et al 1991) receptors, and the $D_{2}$-like family consists of the $D_{2}$ (Grandy et al 1989), $D_{3}$ (Giros et al 1990), and $D_{4}$ (Van Tol et al 1991) receptors. In addition to $D_{1}$ and $D_{2}$ receptor localization in both the motor and limbic dopamine circuits, the $D_{3}$ and $D_{4}$ receptors also appear to be expressed in these systems, with particular enrichment in the limbic circuit (Bouthenet et al 1991; Mengod et al 1992; Lévesque et al 1992). The $D_{1}$ and $D_{2}$ receptors, however, are present in overwhelming abundance compared to the other dopamine receptor subtypes.

The present study was designed to characterize the effects of chronic cocaine use on dopamine receptor binding as well as messenger RNA expression in the postmortem human brain. The focus was on the striatal and accumbens regions, which are heavily innervated by dopaminergic fibers originating in the midbrain, and contain high densities of dopamine receptors. We have initially chosen to focus on the $D_{1}$ and $D_{2}$ receptors, as they are the most abund ant and best understood of the five dopanine receptors in the circuits und examination.

\section{Methods}

BRaIN ACQuisition. Postmortem human brain specimens were obtained at autopsy from subjects suspected of chronic cocaine use, as well as from age-, gender-, and race-matched controls who were not suspected of recent substance abuse (Table 1). These autopsies were authorized and performed by the Office of the Chief Medical Examiner, State of North Carolina, who found no evidence of neurological disease. Two blocks of brain tissue were obtained at autopsy: a midbrain slice containing the substantia nigra and ventral tegmental area, and a rostral forebrain block containing the caudate, putamen, and nucleus accumbens. These two blocks were frozen on powdered dry ice, and stored at $-80^{\circ} \mathrm{C}$. Nine pairs of midbrain blocks were obtained for this study, but only six pairs of the forebrain blocks were available.

Clinical Characterization. A research psychiatrist and a psychologist identified and interviewed informants for each subject. In all cases, an attempt was made to identify family members who could provide historical information. Informants included family members, neighbors, co-workers, police officers, physicians, medical ex- aminers, and media reporters. Interviews were conducted to obtain information to determine if subjects met DSMIII-R criteria (American Psychiatric Association 1987) for affective, anxiety, psychotic, and/or psychoactive substance abuse disorders. After collection of these clinical data, DSM-III-R diagnoses were assigned at a consensus conference involving experienced research psychiatrists. For some subjects, insufficient evidence was obtained to determine if criteria were met for a formal DSM-III-R cocaine-related diagnosis; nevertheless, in these cases, subjects were clearly established to be chronic cocaine users. The presence or absence of cocaine was confirmed in urine, liver, or serum samples from all subjects by thin layer chromatography.

TISSUE PREParation. Blocks that were obtained at the time of autopsy remained at $-80^{\circ} \mathrm{C}$ until the time of study. Each block was slowly warmed to $-20^{\circ} \mathrm{C}$ and mounted for cryostat sectioning. Sections were cut $20 \mu \mathrm{m}$ thick, and were thaw-mounted onto poly-L-lysine subbed $50 \times 75 \mathrm{~mm}$ microscope slides. Sections were dried and stored at $-80^{\circ} \mathrm{C}$ until further processing.

IN SITU HYBRIDIZATION. Sections were removed from $-80^{\circ} \mathrm{C}$ storage and placed in $4 \%$ formaldehyde at $4^{\circ} \mathrm{C}$. Slides were fixed for $60 \mathrm{~min}$, and then processed for in situ hybridization as previously described (Meador-Woodruff et al 1989; Mansour et al 1990; Meador-Woodruff et al 1991). Slides were hybridized with [ ${ }^{35}$ S]-UTP labeled riboprobes in $75 \%$ formamide hybridization buffer at $55^{\circ} \mathrm{C}$ overnight. Following hybridization, slides were treated with RNase $A$, and washed under progressively more stringent conditions, culminating with a $60 \mathrm{~min}$ wash in $0.5 \times$ SSC (300 mmol/L NaCl, $30 \mathrm{mmol} / \mathrm{L}$ sodium citrate, $\mathrm{pH} 7.2$ ) at $55^{\circ} \mathrm{C}$. The slides were then dehydrated in graded alcohols, air-dried, and apposed to Kodak XAR-5 film for 1-3 weeks.

A riboprobe to the human $D_{1}$ receptor probe was synthesized using SP6 RNA polymerase, from a 396 base pair (bp) fragment that was subcloned into pGEM-3Z. This insert is a $\mathbf{B g} \mathbf{l l}$-Hind III fragment of a genomic clone for the human $D_{1}$ receptor (bases 208-603), which encodes the region of the $D_{1}$ receptor between transmembrane domains II and $\mathrm{V}$ and containing the second intracytosolic loop. The $D_{2}$ receptor probe was synthesized using $T 7$ RNA polymerase from a 446 bp fragment subcloned into pGEM-4. This insert contains the region encoding the third intracytosolic loop and transmembrane domains VI and VII of this receptor, and corresponds to bases 1044-1489 of a human $D_{2}$ receptor cDNA. This $D_{2}$ probe equally recognizes both the short and long isoforms of $D_{2}$ receptor messenger ribonucleic acid (mRNA).

A series of technical control studies was performed to 
ensure the specificity of each riboprobe used in this study, as we have previously described (Meador-Woodruff et al 1989; Mansour et al 1990; Meador-Woodruff et al 1991). Both "sense-strand" and RNase-pretreated "antisense"-labeled sections were run in parallel with "antisense"-labeled sections. Under the stringent conditions used in this study, specific hybridization was observed only in the "antisense"-labeled condition.

ReCePtor autoradiography. Preliminary studies were performed on slide-mounted human brain sections to determine the affinities of $\left[{ }^{3} \mathrm{H}\right]$ raclopride $(69.5 \mathrm{Ci} / \mathrm{mmol}$, New England Nuclear) and $\left[{ }^{3} \mathrm{H}\right] \mathrm{SCH} 23390(85.6 \mathrm{Ci} / \mathrm{mmol}$, New England Nuclear), selective $D_{2}$ and $D_{1}$ receptor ligands, respectively. Repeated saturation studies using concentrations of $0.75-10 \mathrm{nmol} / \mathrm{L}$ of tritiated ligand suggested that $\left[{ }^{3} \mathrm{H}\right]$ raclopride had a mean $K_{d}$ of $1.62 \mathrm{nmol} / \mathrm{L}$ and [ $\left.{ }^{3} \mathrm{H}\right] \mathrm{SCH} 23390$ (in the presence of 1 umol/L ketanserin) had an affinity of $3.17 \mathrm{nmol} / \mathrm{L}$ in human brain tissue. These values were valuable in choosing the ligand concentrations in normal and cocaine-exposed brains. Three ligand concentrations were used; one at the $K_{d}$ value, a second at 1/10the $K_{d}$ and a third high concentration three times the $K_{d}$. For $\left[{ }^{3} \mathrm{H}\right]$ raclopride, these corresponded to $0.17,1.55$ and $4.09 \mathrm{nmol} / \mathrm{L}$. For $\left[{ }^{3} \mathrm{H}\right] \mathrm{SCH} 23390$, the concentrations were $0.28,2.97,9.10 \mathrm{nmol} / \mathrm{L}$. All incubations with $\left[{ }^{3} \mathrm{H}\right] \mathrm{SCH} 23390$ also contained $1 \mu \mathrm{mol} / \mathrm{L}$ ketanserin to block any binding to $5 \mathrm{HT}_{2}$ receptors. Nonspecific $\mathrm{D}_{2}$ binding was defined by $I \mu \mathrm{mol} / \mathrm{L}$ ( + )butaclamol while nonspecific $D_{1}$ binding was evaluated with I $\mu \mathrm{M} \mathrm{SCH} 23390$. Although three concentrations are not normally sufficient to determine $K_{d}$ and $B_{\operatorname{mux}}$ values, the limited availability of tissue made a more modified procedure necessary.

Prior to incubation with the tritiated ligands all slides were preincubated $15 \mathrm{~min}\left(22^{\circ} \mathrm{C}\right)$ in a $50 \mathrm{mmol} / \mathrm{L}$ Tris buffer (pH 7.4), containing $120 \mathrm{mmol} / \mathrm{L} \mathrm{NaCl}, 5 \mathrm{mmol} / \mathrm{L}$ $\mathrm{KCl}$, and $1 \mathrm{mmol} / \mathrm{L} \mathrm{MgCl}_{2}$. Slides were then dried and 2 $\mathrm{ml}$ of $\left[{ }^{3} \mathrm{H}\right]$ ligand and buffer $(50 \mathrm{mmol} / \mathrm{L}$ Tris $(\mathrm{pH} 7.4)$, $120 \mathrm{mmol} / \mathrm{L} \mathrm{NaCl}, 5 \mathrm{mmol} / \mathrm{L} \mathrm{KCl}, 1 \mathrm{mmol} / \mathrm{L} \mathrm{MgCl}_{2}$, $0.1 \%$ ascorbic acid) at the three concentrations indicated earlier was applied to the brain sections. Adjacent sections were used to evaluate nonspecific binding at each ligand concentration. Incubations were terminated at $90 \mathrm{~min}\left(22^{\circ} \mathrm{C}\right)$ by four 2 -min $\left(\left[{ }^{3} \mathrm{H}\right]\right.$ raclopride $)$ or $4 \min \left(\left[{ }^{3} \mathrm{H}\right] \mathrm{SCH} 23390\right)$ Tris washes $\left(50 \mathrm{mmol} / \mathrm{L} \mathrm{pH} 7.0,4^{\circ} \mathrm{C}\right)$ containing 120 $\mathrm{mmol} / \mathrm{L} \mathrm{NaCl}, 5 \mathrm{mmol} / \mathrm{L} \mathrm{KCl}, 1 \mathrm{mmol} / \mathrm{L} \mathrm{MgCl}_{2}$ and $0.1 \%$ ascorbic acid. Slides were then dipped into distilled water $\left(4^{\circ} \mathrm{C}\right)$, dried with a hair dryer set to cool, and apposed to tritium sensitive Hyperfilm (Amersham) with calibrated radioactive standards.

DaTA ANALYSIS. Films from in situ hybridization and receptor autoradiography experiments were digitized and optical densities in anatomical regions of interest were evaluated using quantitative densitometry. Regions of interest for this study included the nucleus accumbens, caudate, and putamen for all riboprobes and radioligands; the pars compacta of the substantia nigra for $D_{2}$ receptor mRNA and binding; and the pars reticulata of the substantia nigra for $D_{1}$ receptor binding. Although the ventr"' tegmental area was identifiable in the midbrain blocks with a riboprobe to tyrosine hydroxylase mRNA, the probes used in this study did not generate a signal that was sufficient to convincingly quantify.

For in situ hybridization films, mean optical density values were obtained for each region studied for each probe from 8-10 slides per subject. These values were averaged to provide a single value for each region and each probe for each subject. For quantification of receptor binding, the optical density for each region of interest was converted to fmoles of ligand bound using calibrated tritium standards. Nonspecific binding was subtracted at each ligand concentration in each anatomical structure, and the values were fitted to Scatchard plots using the LIGAND program (Munson and Rodbard 1980). The $K_{d}$ and $B_{\max }$ obtained from these data points agreed well with previous results using a larger series of concentrations. In all cases, mean values were compared by paired two-tailed $t$-tests, with $p<0.05$ selected to define significant differences.

\section{Results}

ClinCIAL ASSESSment. As shown in Table 1, cocaine-abusing and control subjects were well matched for age, gender, race, and postmortem interval. There were no significant differences between the two groups for any of these items. All of the cocaine-abusing subjects were determined to be chronic cocaine users, and all had positive toxicology for cocaine at the time of death. None of the control subjects had evidence for a substance abuse or significant axis I psychiatric diagnosis, and all were free of cocaine by toxicological analysis at the time of death.

DOPAMINE RECEPTOR EXPRESSION. As Shown in Figure 1 , there were $n n$ significant differences between the cocaine-abusing and control groups for dopamine $D_{1}$ or $D_{2}$ receptor $m R N A$ or binding in any of the three forebrain structures studied. Similarly, as demonstrated in Figure 2, $D_{2}$ receptor binding and mRNA as well as $D_{1}$ receptor binding were not significantly different between these groups in the substantia nigra. The ventral tegmental area was poorly visualizable in these subjects. A comparison was made of the medial versus lateral portions of the cells that were identifiable in the midbrain, however; there were neither medial-lateral differences within either subject group, nor were there differences between the groups when com- 
Table 1. Clinica! and Demographic Characteristics of Subjects

\begin{tabular}{|c|c|c|c|c|c|c|c|}
\hline \multicolumn{4}{|c|}{ Cocaine subjects } & \multicolumn{4}{|c|}{ Control subjects } \\
\hline Age & Race/gender & PMI & Mode of death & Age & Race/gender & PMI & Mode of death \\
\hline 28 & $\mathbf{B} / \mathbf{F}$ & 20 & stabbing & 30 & $\mathrm{~B} / \mathrm{F}$ & 14 & cardiac \\
\hline 24 & W/M & 9 & stabbing & 27 & W/M & 8 & stabbing \\
\hline 32 & $\mathbf{W} / \mathbf{M}$ & 18 & cardiac & 24 & W/M & 12 & gsw \\
\hline 29 & $\mathbf{W} / \mathbf{M}$ & 8 & gsw & 24 & $\mathbf{W} / \mathbf{M}$ & 16 & ? cardiac \\
\hline 37 & $\mathbf{B} / \mathbf{F}$ & 9 & overdose (cocaine) & 33 & $\mathrm{~B} / \mathrm{F}$ & 9 & ? cardiac \\
\hline 21 & $\mathbf{B} / \mathbf{F}$ & 7 & gsw & 29 & $\mathbf{B} / \mathbf{F}$ & 10 & stabbing \\
\hline 36 & $\mathrm{~B} / \mathrm{M}$ & 5 & overdose (cocaine) & 20 & $\mathbf{B} / \mathbf{M}$ & 16 & mva \\
\hline 39 & $\mathbf{B} / \mathbf{M}$ & 7 & overdose (cocaine) & 41 & $\mathbf{B} / \mathbf{M}$ & 16 & gsw \\
\hline 36 & $W / F$ & 8 & cardiac & 25 & $\mathbf{W} / \mathbf{F}$ & 11 & gsw \\
\hline
\end{tabular}

PMI: postmortem interval (hours); gsw: gunshot wound; mva: motor vehicle accident.

paring just the medial or lateral aspects of the substantia nigra (data not shown).

\section{Discussion}

Dopamine $D_{1}$ and $D_{2}$ receptor expression were not significantly different between cocaine-abusing subjects and controls in any of the three forebrain dopaminoiceptive regions studied, or in midbrain dopamine-containing cells.

Previous reports on the effects of cocaine on brain $D_{2}$ receptor expression in rats have found different effects in the nucleus accumbens versus the striatum. Immediately following chronic cocaine treatment in the rat, $D_{2}$ receptor binding has been reported consistently to be elevated in the nucleus accumbens (Trulson and Ulissey 1987; Goeders and Kuhar 1987; Kleven et al 1990; Peris et al 1990). Conversely, results in the striatum have bien variable, being reported as both elevated (Trulson and Ulissey 1987) and decreased (Goeders and Kuhar 1987; Kleven et al 1990). In most studies finding an increase in the accumbens, $D_{2}$ receptor binding had returned to normal levels a week after discontinuation of cocaine (Kleven et al 1990; Peris et al 1990).

Several reports of $D_{1}$ receptor binding following chronic cocaine treatment in the rat have also been published. In one, both striatal and accumbens $D_{1}$ receptor binding were found to be decreased immediately following treatment, with the accumbens but not the striatal levels normalizing within a week or two (Kleven et al 1990). Another study, however, found no changes in either striatal or accumbens $D_{1}$ receptor binding following a week of cocaine treatment (Mayfield et al 1992).

Because species differences may complicate comparison with the current human findings, primate studies are of special note. In particular, the size, location, and possible functional significance of the nucleus accumbens differ in primates versus rodents. One study has examined dopamine and other neurotransmitter systems in the rhesus monkey following chronic cocaine exposure (Farfel et al 1992). In contrast to the rat, $D_{2}$ receptor binding in the accumbens, caudate, and substantia nigra was unchanged. A significant decrease in $D_{1}$ binding in the caudate was found, however, with no effect in the accumbens. Similarly, although not statistically significant, there is a trend toward decreased levels of $D_{1}$ receptor mRNA in forebrain structures in the present data. $D_{1}$ receptor binding, however, showed equivalent levels in cocaine-using and control subjects, suggesting that translational compensation may have occurred in the face of an alteration in gene transcription.

The effect of cocaine on $D_{2}$ receptor binding in the human has also been studied in vivo using positron emission tomography (PET) (Volkow et al 1990). Cocainedependent subjects who were withdrawn from cocaine in the week prior to study exhibited a decrease in apparent $D_{2}$ receptor binding (as determined by $\left[{ }^{18} \mathrm{~F}\right] \mathrm{N}$-methylspiroperidoi upiake) in the striatum. In contrast, cocainedependent subjects who had been abstinent for 3 weeks were not distinct compared to controls. In our data, there is no suggestion of $a D_{2}$ receptor alteration in any forebrain structure. It is somewhat difficult to reconcile these findings, but may well be related to any number of technicai factors, including the use of different radioligands, kinetic assumptions made in the PET study, differing limits of resolution of the two techniques, and differences in what is actually measured in each study (i.e., striatal uptake of the tracer in the PET study versus binding of radioligand to brain tissue in the present work). As Volkow and associates indicate in their report, the use of $\mathrm{N}$-methylspiroperidol in PET to estimate $D_{2}$ receptor availability is an area of controversy.

A critical limitation in comparing results from animal experiments to the present data is the potential difference in frequency of administration of cocaine. In these past rodent studies, cocaine was administered at regularly scheduled intervals related to drug half-life, presumably 

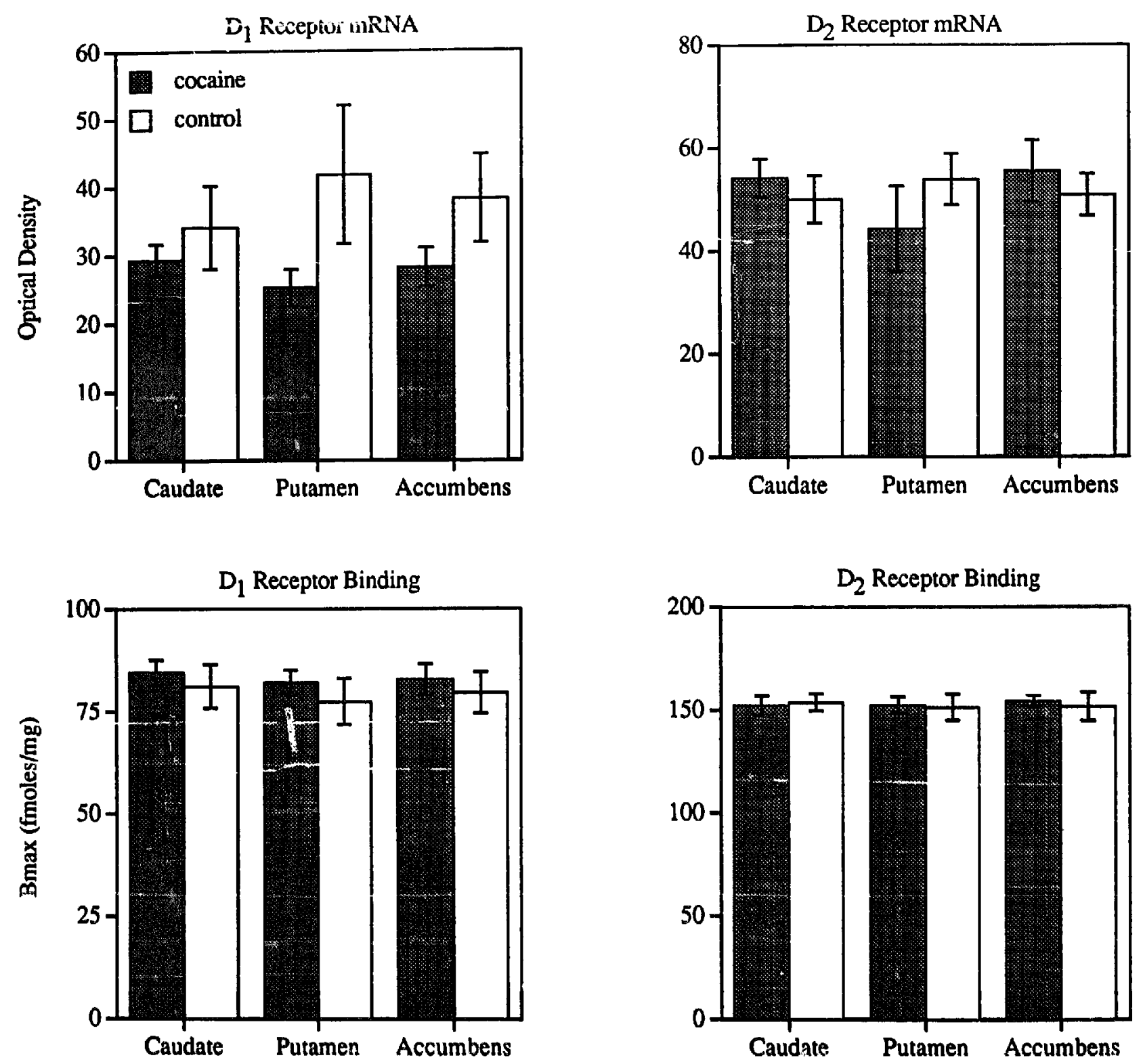

Figure 1. Dopamine receptor binding and mRNA in forebrain structures. Dopamine $D_{1}$ and $D_{2}$ receptor binding were determined with $\left[{ }^{3} \mathrm{H}\right] \mathrm{SCH} 23390$ and $\left[{ }^{3} \mathrm{H}\right]$ raclopride, respectively, and $\mathrm{D}_{1}$ and $\mathrm{D}_{2}$ receptor mRNAs with $\left[{ }^{35} \mathrm{~S}\right]$-labeled riboprobes. Results are $\mathrm{mt}$ ans $\pm \mathrm{SEM}$ for $n=6$ subjects per group. None of the differences between control and cocaine-abusing subjects are significant.

to maintain sustained brain levels of this drug throughout the experiment. In the cocaine-abusing human, however, it is unreasonable to expect that the drug will be ingested on a regular basis for extended periods due to a number of factors, including access and availability of the drug. A more likely pattern of cocaine use in the cocaine-dependent human subject is binging, which could be described as intense but intermittent exposure. None of the animal studies reviewed above included self-administration, which may best model the human intake pattern. It appears that these two receptors are extremely plastic during and after cocaine treatment, as demonstrated by the rapid normalization of their expression following cocaine withdrawal in these rat studies. The negative findings presented in the current work represent dopamine receptor status at one uncontrolled time point along a dynamic continuum, and the absence of apparent regulation may not be altogether unexpected.

In contrast, cocaine exposure appears to increase binding to the presynaptically located dopamine transporter. 


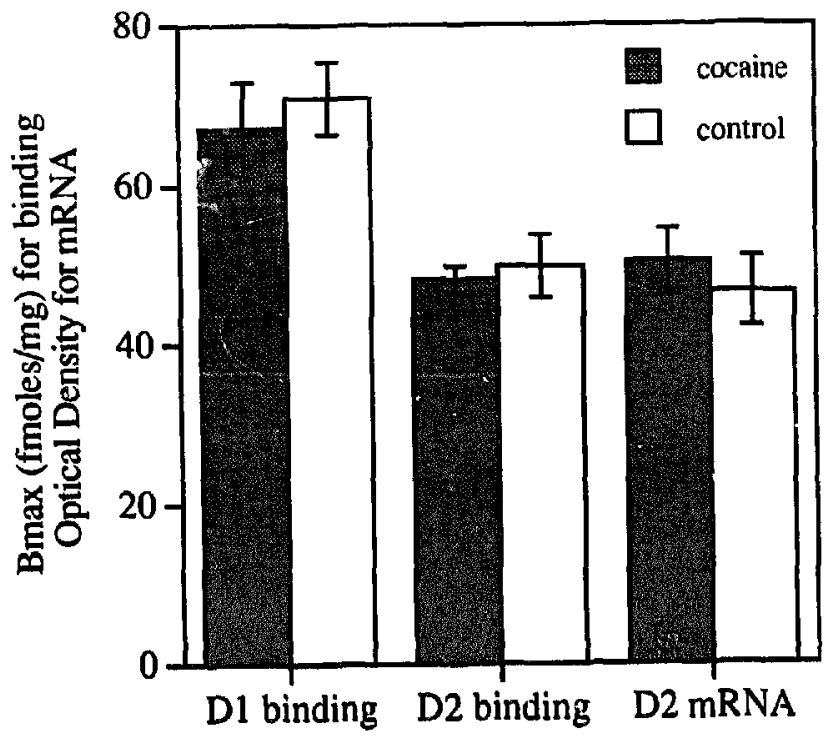

Figure 2. Dopamine receptor binding and mRNA in the substantia nigra. Dopamine $D_{1}$ and $D_{2}$ receptor binding were determined with $\left[{ }^{3} \mathrm{H}\right] \mathrm{SCH} 23390$ and $\left[{ }^{3} \mathrm{H}\right]$ raclopride, and $\mathrm{D}_{2}$ receptor mRNA with a $\left[{ }^{35} \mathrm{~S}\right]$-labeled riboprobe. Results are presented as means \pm SEM with $n=9$ subjects per group. None of the differences between control and cocaine-abusing subjects are significant.

withdrawal in these rat studies. The negative findings presented in the current work represent dopamine receptor status at one uncontrolled time point along a dynamic continuum, and the absence of apparent regulation may not be altogether unexpected.

In contrast, cocaine exposure appears to increase binding to the presynaptically located dopamine transporter. Striatal tissue from many of these same subjects included in the present study was found to demonstrate a significant increase in $\left[{ }^{3} \mathrm{H}\right]$ WIN35428 (a cocaine congener) binding (Little et al 1992). In addition to suggesting that the dopamine transporter is regulated by cocaine in the human, these particular data indicate that the lack of regulation of the $D_{1}$ and $D_{2}$ receptors in our present work was not caused by the lack of chronic cocaine exposure in the subjects.

There are several limitations to this study that need to be acknowledged. By its very design, a postmortem study is retrospective, especially in terms of diagnosis and assessment. Although the chronicity of use of cocaine is unquestioned in this subject group, it is unfortunately reconstructed from informants. The relatively small number of subjects availahle may also be a factor in explaining the lack of statistical findings, but with most group means as close as they were, this is unlikely. Postmortem studies inherently study a subject at a single point in time, lacking the ability to follow a subject, or the regulation of a system, in a longitudinal fashion. Despite these limitations, however, at the present time, postmortem analysis appears to be the only method that is available to image specific gene products (i.e., receptor mRNA) in the human brain.

By examining the mRNAs encoding these dopamine receptors, the present study provides an additional level of neurochemical information that has not been previously available. The simultaneous examination of both binding sites and mRNA provides distinct but complementary information. By examining both mRNA as well as receptor binding, the products of transcription and translation can be both indirectly accessed. In addition, the combined use of these data provides insight into discrete neuroanatomical circuits. $\mathrm{D}_{2}$ receptor binding in the midbrain is likely all local, and reflects receptors functioning as autoreceptors in the midbrain. $D_{2}$ receptor mRNA in the midbrain encodes receptors that remain in the midbrain, presumably serving as autoreceptors, as well as encoding autoreceptors that exist in terminals in the forebrain. $D_{1}$ receptor binding in the midbrain is encoded in the forebrain, which is expressed as receptors on terminals in the pars reticulata of the substantia nigra. As all of this $D_{1}$ receptor binding is encoded by mRNA in cells located more rostrally, no $D_{1}$ receptor mRNA is seen in the mesencephalon; rather, the mRNA encoding midbrain $D_{1}$ receptors is located in the forebrain. $D_{1}$ and $D_{2}$ receptor mRNA in the forebrain structures is all associated with intrinsic cells in the regions of interest. $D_{2}$ receptor binding likely is on cell processes of both intrinsic cells, as well as on terminals from neurons projecting from other regions, such as the cortex; additionally, some $D_{2}$ binding reflects autoreceptors that are encoded in the substantia nigra, and is thus associated with some of the $D_{2}$ receptor mRNA visualized in the nigra. $D_{1}$ receptor binding in the forebrain is in large part on cellular processes from intrinsic cells in the forebrain structures. As can be seen, this circuitry is complex, and these data provide information concerning the regulation (or lack thereon of multiple functional and anatomical levels of neural organization.

Other subtypes of dopamine receptors exist, especially in the limbic system. Although the $D_{5}$ receptor is not located in the limbic or motor dopamine systems (Tiberi et al 1991; Meador-Woodruff et al 1992), $D_{3}$ and $D_{4}$ receptors are present in the limbic system (Bouthenet et al 1991; Van Tol et al 1991; Mengod et al 1992; Lévesque et al 1992), although at low levels of expression. It may be interesting to determine if one or the other of these putatively more "limbic" receptors is influenced by chronic cocaine in the human. This may be difficult at this time, however, due to the low abundance of mRNAs encoding these receptors, as well as due to the lack of a $D_{4}$-specific ligand for receptor autoradiography. 
Dr. Meador-Woodnuff is the recipient of a Research Scientist Development Award from NIMH (MH00818). This work was also supported by MH42251 (SJW) and The Foundation of Hope for Research and Treatment of Mental IIIness (KYL). The authors wish to thank Carolyn
Work, Rebekah Kuehn, and Jennifer Saul for their enthusiastic technical contributions to this work. The assistance of the Office of the Chief Medical Examiner, State of North Curolina (John D. Butts, M.D., Chief) is gratefully acknowledged.

\section{References}

American Psychiatric Association (1987): in Diagnostic and Statistical Manual of Mental Disorders, 3rd ed rev. Washington, DC: American Psychiatric Press.

Bouthenet M-L, Souil E, Martres M-P, Sokoloff P, Gitos B, Schwartz J.C (1991): Localization of dopamine $D_{3}$ receptor mRNA in the rat brain using in situ hybridization histochemistry: comparison with dopamine $D_{2}$ receptor mRNA. Brain Res 564:203-219.

Church W, Justice J Jr. Byrd L (1987): Extracellular dopamine in rat striatum following uptake inhibition by cocaine, nomifensive and benztropine. Eur J Pharmacol 139:345-348.

Dearry A, Gingrich JA, Fallardeau P, Freameau RT Jr., Bates MD, Caron MG (1990): Molecular cloning and expression of the gene for a human $D_{1}$ receptor. Nature 347:72-75.

Farfel GM, Kleven MS, Woolverton WL,Seiden LS, Perry BD (1992): Effects of repeated injections of cocaine on catecholamine receptor binding sites, dopamine transporter binding sites and behavior in rhesus monkey. Brain Res 578:235243.

Giros B, Martres M-P, Sokoloff P, Schwartz J-C (1990): Clonage

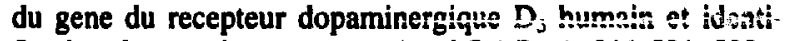
fication de son chromosome. Acad Sci Paris 311:501-508.

Goeders NE. Kuhar MJ (1987): Chronic cocaine administration induces opposite changes in dopamine receptors in the striatum and nucleus accumbens. Alcohol Drug Res 7:207-216.

Grandy DK, Marchionni MA, Makam H, et al (1989): Cloning of the cDNA and gene for a human $D_{2}$ dopamine receptor. Proc Natl Acad Sci USA 86:9762-9766.

Grandy DK, Zhang Y, Bouvier C, et al (1991): Multiple human $\mathrm{D}_{5}$ dopamine receptor genes: a functional receptor and two pseudogenes. Proc Natl Acad Sci USA 88:9175-9179.

Izenwasser S. Werling L, Cox B (1990): Comparison of the effects of cocaine and other inhibitors of dopamine uptake in rat striatum, nucleus accumbens, olfactory tubercle, and medial prefrontal cortex. Brain Res 520:303-309.

Kleven MS, Perry BD, Woolverton WL, Seiden LS (1990); Effects of repeated injections of cocaine on $D_{1}$ and $D_{2}$ dopamine receniors in rat brain. Brain Res 532:265-270.

Kuhar M, Ritz M, Boja J (1991): The dopamine hypothesis of the reinforcing properties of cocaine. Trends Newrosci 14:29y 302.

Lévesque D, Diaz J, Pilon C. et al (1992): Identification, characterization, and localization of the dopamine $D_{3}$ receptor in rat brain using $7-\left[{ }^{3} \mathrm{H}\right]$ hydroxy- $N, N$-di-n-propyl-2-aminotetalin. Proc Natl Acad Sci USA 89:8155-8159.

Little KY, Kirkman JA, Carnoll FI, Duncan GE (1992): Brain ${ }^{125}$ I-RTI-55 and ${ }^{3} \mathrm{H}$-CFT binding in normal and cocaine-abusing human subjects. Soc Neurosci Abstracts 18:542.

Mansour A, Meador-Woodruff JH, Bunzow JR, Civelli O, Akil
$H$, Watson SJ (1990): Localization of dopamine $D_{2}$ receptor $m R N A$ and $D_{1}$ and $D_{2}$ receptor binding in the rat brain and pituitary: an in situ hybridization-receptor autoradiographic analysis. $J$ Neurosci 10:2587-2600.

Mayfield RD, Larson G, Zahniser NR (1992): Cocaine-induced behavioral sensitization and $D_{1}$ dopamine receptor function in rat nucleus accumbens and striatum. Brain Res 573:331335.

Meador-Woodruff JH, Mansour A, Bunzow JR, Van Tol HHM, Watson SJ Jr., Civelli O (1989): Distribution of $D_{2}$ dopamine receptor mRNA in rat brain. Proc Nall Acad Sci USA 86:76257628.

Meador-Woodruff JH,Mansour A, Healy DJ, et al (1991): Comparison of the distributions of $D_{1}$ and $D_{2}$ dopamine receptor mRNAs in rat brain. Neuropsychopharmacology 5:231-242.

Meador-Woodruff JH, Mansour A, Grandy DK, Damask SP, Civelli O, Watson SJ (1992): Distribution of $D_{5}$ dopamine receptor mRNA in rat brain. Neurosci Lett 145:209-212.

Mengod G, Villaró MT, Landwehrmeyer GB, et al (1992): Visualization of dopamine $D_{1}, D_{2}$, and $D_{3}$ receptor $m R N A s$ in human and rat brain. Neurochem Int suppl 20:33S-43S.

Munson P, Rodbard D (1980): Ligand: a versatile computerized approach for characterization of ligand-binding systems. Anal Biochem 107:220-239.

Peris J, Boyson SJ, Cass WA, et al (1990): Persistence of neurochemical changes in dopamine systems after repeated cocaine administrution. J Pharmacol Exp Ther 253:38-44.

Ritz M, Lamb R, Goldberg S, Kuhar M (1987): Cocaine receptors on dopamine transporters are related to self-administration of cocaine. Science 237:1219-1223.

SLnahara RK, Guan H-C, O'Dowd BF, et al (1991): Cloning of the gene for a human dopamine $D_{5}$ receptor with higher affinity for dopamine than $D_{1}$. Nature 350:614-619.

Sunahara RK, Niznik HB, Weiner DM, et al (1990): Human D, receptor encoded by an intronless gene on chromosome 5 . Nature 347:80-83.

Tiberi M, Jarvie KR, Silvia C, et al (1991): Cloning, molecular characterization, and chromosomal assignment of a gene encoding a second $D_{1}$ dopamine receptor subtype: differential expression pattem in rat brain compared with the $D_{1 A}$ receptor. Proc Natl Acad Sci USA 88:7491-7495.

Trulson ME, Ulissey MJ (1987): Chronic cocaine administration decreases dopamine synthesis rate and increases $\left[{ }^{3} \mathrm{H}\right]$ spiroperidol binding in rat brain. Brain Res Bull 19:35-38.

Van Tol HHM, Bunzow JR, Guan HC, et al (1991): Cloning of the gene for a human dopamine $D_{4}$ receptor with high affinity for the antipsychotic clozapine. Nature 350:610-614.

Volkow ND, Fowler JS, Wolf AP, et al (1990): Effects of chronic 
cocaine abuse on postsynaptic dopanine receptors. Am J Psychiatry 147:719-724.

Weinshank RL, Adham N, Macchi M, Olsen MA, Branchek TA, Hartig PR (1991): Molecular cloning and characterization of a high affinity dopamine receptor $\left(D_{1 \beta}\right)$ and its pseudogene.
$J$ Biol Chem 266:22427-22435.

Zhou QY, Grandy DK, Thambi L, et al (1990): Cloning and expression of human and rat $D_{1}$ dopamine receptors. Nature 347:76-80. 